\title{
Pregnancy, embryo-fetal development and nutrition: physiology around fetal programming
}

\author{
Giuseppe Musumeci ${ }^{*}$, Paola Castrogiovanni ${ }^{1}$, Francesca Maria Trovato ${ }^{2}$, Rosalba Parenti ${ }^{3}$, Marta Anna Szychlinska ${ }^{1}$ and Rosa Imbesi ${ }^{1}$ \\ ${ }^{*}$ Correspondence: g.musumeci@unict.it

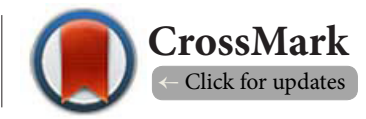 \\ 'Department of Biomedical and Biotechnological Sciences, Human Anatomy and Histology Section, School of Medicine, \\ University of Catania, Catania, Italy. \\ ${ }^{2}$ Department of Medical and Pediatric Sciences, Internal Medicine Division, University of Catania, Catania, Italy. \\ ${ }^{3}$ Department of Biomedical and Biotechnological Sciences, Physiology Section, School of Medicine, University of Catania, \\ Catania, Italy.
}

\begin{abstract}
The purpose of this brief narrative review is to highlight the role of nutrition during the gestation period. We focused on the possible effects of imbalance of some nutrients in normal course of pregnancy and embryonic development. We discussed about changes in nutritional and/or hormonal embryonic microenvironment, which represent the basis of a phenomenon known as "fetal programming". We strongly believe that the understanding of these events can be a valuable tool in order to prevent the onset of disorders and diseases in postnatal life.
\end{abstract}

Keywords: Infant feeding, malnutrition, nutritional support, nutritional surveillance, pregnancy

\section{Introduction}

Experimental observations clearly indicate that during pregnancy, the pre-implantation phase is the period of the greatest vulne rability for the future embryo in relation to several endogenous and/or exogenous factors, including those nutritional ones [1-3]. In mice, the nutritional stress, during the pre-implantation phase, is often responsible of blastocyst death and pregnancy block [4]. Reduction, deprivation or imbalance of nutrients in the very early stages of pregnancy, before implantation, results not only in an obvious impaired somatic development at birth $[5,6]$, but also in the profound alterations of endocrine and metabolic functions [7] and, often, in the impaired maturation of reproductive system in postnatal life [8]. In addition, observations from clinical, epidemiological and experimental studies in vivo and in vitro, showed that different nutrients seem to be able to influence both the normal course of pregnancy and the embryo-fetal development in different animal species, including humans (Figure 1) [1-3]. Experimental results showed that undernutrition during pregnancy significantly reduces the number of infants in mice, by increasing the phenomenon of fetal resorption and neonatal mortality [9]; in sheep, it defers intrauterine development of the fetus [10] and in rats, it reduces the weight of pups at birth [8] (Table 1). In case of a severe maternal undernutrition, due to reduced caloric intake, there is a proportional increase in catabolic activity of maternal tissues that results in the release into the maternal-fetal circulation of many amino acids, vitamins and minerals, which are able to balance the insufficient "diet" of the fetus. Instead, when we consider the selective essential micronutrients during the embryo-fetal development, the insufficient intake of some of them is clearly associated with some malformation syndromes, such as neural tube birth defects related to insufficient amounts of folic acid and vitamins C, B6 and B12 [11,12]. The purpose of this brief narrative review is to emphasize the importance of nutrition before and during pregnancy, as the mother is the source of all the molecular elements that help to regulate growth and development of the embryo until birth.

\section{Review}

\section{Nutritional deficiencies in preconception period}

Sexual reproduction is a phenomenon that begins before fertilization. It can be realized thanks to the existence of the germ line and the subsequent gametogenesis, which takes place during the puberty. The literature provides more and more information about the consequences of nutritional deficiencies in parental germ cells, even before the fertilization of the egg 


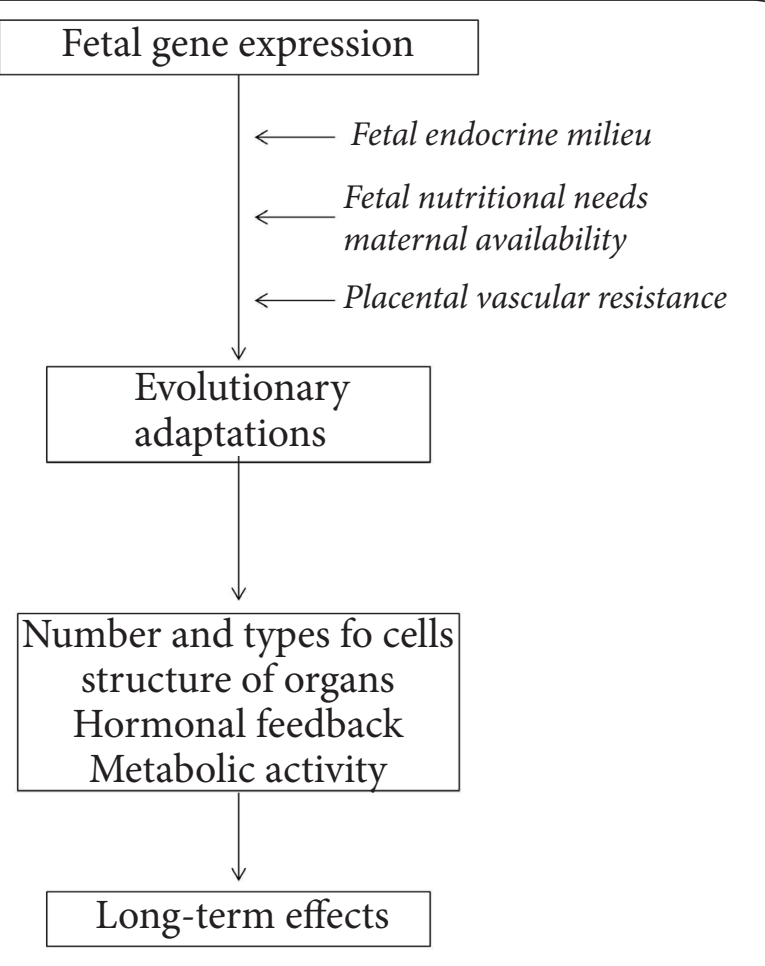

Figure 1. Diagram of interrelations between fetal development and long-term effects on its body.

Table 1. Effects of micronutrients intake on female reproductive activity.

\begin{tabular}{ll}
\hline Supplements & Significant effects \\
\hline Calcium & $\begin{array}{l}\text { Reduction of symptoms related to PMS } \\
\text { Reduction of the preeclampsia effects in } \\
\text { high-risk pregnancy } \\
\text { The maternal intake of calcium improves } \\
\text { bone mineral component ofthe newborn } \\
\text { Reductionintheincidenceofhipfractures } \\
\text { from osteoporosis }\end{array}$ \\
\hline Folic acid & $\begin{array}{l}\text { Prevention of the incidence of NTDs in } \\
\text { the fetus }\end{array}$ \\
\hline Folic Acid+Zinc+ & $\begin{array}{l}\text { Prevention of the incidence of NTDs } \\
\text { multivitamin preparations other birth defects }\end{array}$ \\
& $\begin{array}{l}\text { Prevention of preterm birth } \\
\text { Prevention of a low birth weight }\end{array}$ \\
\hline Multivitamins & $\begin{array}{l}\text { Reduction of the risk of premature } \\
\text { birth and the consequences of hypo- } \\
\text { weight at birth } \\
\text { Minimization of the risk of fetal death } \\
\text { and increase the plasma concentra- } \\
\text { tions of immune cells in HIV-positive } \\
\text { pregnant }\end{array}$ \\
\hline Vitamin A/b-carotene & $\begin{array}{l}\text { Reduction of maternal mortality } \\
\text { Vitamins C and E }\end{array}$ \\
\hline
\end{tabular}

PMS: Premestrual Syndrome; NTDs: Neural tube defects;

HIV: Human immunodeficiency virus cell [13-15]. Recently, it has been shown that damage to DNA in spermatocytes of adults, as a result of micronutrient deficiencies, can significantly increase the risk of congenital malformations and even carcinogenesis in descendants $[16,17]$. Some substances such as cigarette smoking and alcohol can aggravate deficiencies of crucial nutrients such as folate, zinc, vitamins $C, E$ and $A[11,12]$. A condition of undernutrition during the folliculogenesis, a phase characterized by active angiogenesis and protein synthesis, results in a poor quality of the oocyte [18]. Therefore, both in the preconception period and in the earliest stages of embryonic development, the nutritional deficiencies and/or nutrient-gene interactions may be responsible for changes or complications of reproductive process.

\section{Vascular and cardiovascular factors}

Complications of reproductive process become more serious if mediated by vascular and cardiovascular factors [19]. Deficient or abnormal development of placenta and of its vascularization, both in the early stages of pregnancy and in the perinatal period, may also play a substantial role in the control of normal embryonic development $[19,20]$. In this case, many congenital defects are also related, at least in part, to the vascular damage of embryonic tissues [20]. A possible cardiovascular disease in the pregnant women, is often associated with a significant increase of the incidence of body weight reduction in infants [19]. This is related to the reduction of blood flow to the uterus and the consequent reduction in the supply of oxygen and nutrients into the embryo-fetal circulation (Figure 2) [19].

\section{Endocrine and paracrine factors}

A general or selective deficiency of essential nutrients is not the only cause of potential congenital defects. During embryonic tissue growth and differentiation, a number of important

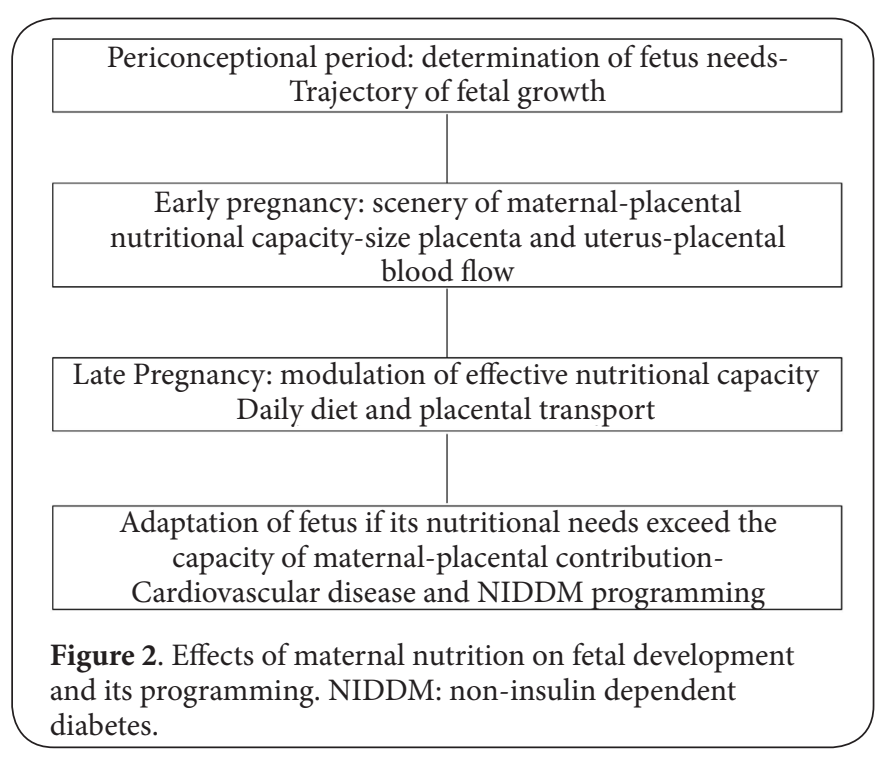


endocrine and paracrine factors, whose action is crucial in the control of reproductive processes, are involved [3]. Among these, a crucial role, not only during embryonic development but also in the course of postnatal life, is played by insulin and insulin-like growth factors (IGFs), which are considered, as amply demonstrated in the experimental animal, the most potent regulators of cell proliferation, apoptosis (especially programmed apoptosis), oogenesis, embryogenesis and ovarian secretion (Table 2) $[2,3,16]$. The role played by serotonin in the diet of pregnant rats has been shown in recent data from

Table 2. Effects on fetal and placental weight in mice in the last stages of gestation according to the distribution of genes that control the bioavailability of IGFs.

\begin{tabular}{|c|c|c|c|}
\hline & & $\%$ of $n$ & ormal weight \\
\hline Gene target & Effects & Fetus & Placenta \\
\hline $\operatorname{Igf1}$ & $\begin{array}{l}\text { Absence of IGF-I in } \\
\text { tissues and plasma }\end{array}$ & 60 & 100 \\
\hline $\operatorname{Igf2}$ & $\begin{array}{l}\text { Absence of IGF-II } \\
\text { reduction of placental }\end{array}$ & 60 & 75 \\
\hline Placental PO Igf2 & $\begin{array}{l}\text { IGF-II } \\
\text { normal fetal IGF-II }\end{array}$ & 75 & 65 \\
\hline IGF-Type I & $\begin{array}{l}\text { No response from the } \\
\text { receptors for the IGFs }\end{array}$ & 45 & 100 \\
\hline Receptor (IGFIr) & IGF1r & -- & -- \\
\hline IGF-Type 2 & No clearance of IGF-II & 140 & 140 \\
\hline Receptor $(\operatorname{Igf} 2 r)$ & $\begin{array}{l}\text { Increase of plasmatic } \\
\text { IGF-II }\end{array}$ & -- & -- \\
\hline H19 & $\begin{array}{l}\text { No suppression of } \\
\text { maternal IGF-II } \\
\text { Increase of tissue } \\
\text { IGF-II }\end{array}$ & 130 & 140 \\
\hline Igf2 eH19 & $\begin{array}{l}\text { Increase of tissue and } \\
\text { plasmatic IGF-II }\end{array}$ & 200 & 230 \\
\hline
\end{tabular}

literature [16,21-24]. Our recent studies showed that deficiency or absence of L-tryptophan (L-Tp), the precursor of serotonin (5-HT), could be responsible for altered growth and possible alterations in sexual development of descendants of pregnant rats fed with L-Tp free diet [8]. Even the excess of L-Tp in diet of pregnant rats, showed adverse effects on their descendants [25], in particular on muscle tissue development. Indeed, this amino acid has been shown to limit the production of IGF-I by the liver [26], therefore, we could hypothesize the existence of a real 5HT/growth hormone (GH)/IGF-I axis [27]. In humans, there are numerous clinical observations in pregnancy, which may confirm these experimental conclusions. It is known that IGF-I significantly influences the secretion of ovarian steroids (estrogen and progesterone) in human ovary [28]. Nucleotides such as cyclic adenosine monophosphate (cAMP) and guanosine monophosphate (GMP), as intracellular second messengers, may be responsible for mediation or control of the pituitary gonadotropic cells, with obvious effects on ovarian function, and in particular on folliculogenesis. During the intrauterine life, in particular IGF-I, but also IGF-II, play an important role in the regulation of nutrient metabolism (especially in the later stages of pregnancy). Instead, in the immediate neonatal life they promote the use of energy for growth and for the final differentiation of various tissues, especially those of musculo-skeletal and nervous systems, and their progressive adaptation to extrauterine environment [26]. Moreover, IGF-I is important for some essential functions such as the increase of protein synthesis and, at the same time, the limitation of catabolic process [29]. Alterations in the regulation of nutrients in prenatal life may be responsible for the onset of short or long-term endocrine-metabolic disorders such as postnatal insulin resistance, diabetes type 1, obesity and disorders in puberty $[7,30]$. This is the pathophysiological basis for numerous and detailed clinical studies on adults [31-33]. These studies start to highlight the mechanisms that are able to establish a link between the various critical moments of the embryo-fetal development, which are also represented by a rapid cell proliferation, and the eventual diseases of postnatal life.

\section{Fetal programming and immune system}

Nutritional or/and hormonal changes in the embryo-fetal microenvironment, can alter the fetal genomic expression and exert permanent effects on a wide range of physiological processes [34]. This phenomenon is known as "fetal programming" (Table 3). Results from recent researches confirmed that maternal-fetal malnutrition (both hypo- and hyper-nutrition) exerts a suppressive effect on the immune response of both mother and fetus, with inevitable consequences on the deveopment of the immune system of the latter $[35,36]$. Hyponutrition, in fact, evokes a significant hypotrophy of both primary and secondary lymphoid organs. Also hyper-nutrition, especially if characterized by the abundance of fat, may have a suppressive effect on the immune response $[29,35]$. The consequences of

Table 3. Tissues and systems for which there is evidence, in humans, of fetal programming.

\begin{tabular}{|c|c|}
\hline Tissue/systems & Examples of programming \\
\hline \multirow{3}{*}{$\begin{array}{l}\text { Cardiovascular } \\
\text { system }\end{array}$} & Vascular compliance \\
\hline & Thickness of the wall of the left ventricle \\
\hline & Endothelial function \\
\hline Respiratory system & Volume of each lung \\
\hline \multirow[t]{4}{*}{ Endocrine system } & Hypothalamic-pituitary-adrenocortical axis \\
\hline & Insulin metabolism of glucose \\
\hline & GH-IGF-I axis \\
\hline & Hypothalamic-pituitary-gonadal axis \\
\hline \multirow{2}{*}{$\begin{array}{l}\text { Musculo-skeletal } \\
\text { system }\end{array}$} & Insulin resistance \\
\hline & Glycolysis during exercise \\
\hline Bone & Bone mineral content \\
\hline Kidney & Renin-angiotensin system \\
\hline \multirow[t]{2}{*}{ Liver } & Cholesterol metabolism \\
\hline & Synthesis of fibrinogen and factor VII \\
\hline Immune system & Thyroid autoimmunity \\
\hline
\end{tabular}


malnutrition are more severe if present in particular stages of life. Malnutrition during pregnancy is a serious risk for the development of the immune defense of the fetus, both in the intrauterine life and in the postnatal one, when the infant is no longer protected by the maternal defenses [37]. Malnutrition during weaning and in early childhood may result in lasting effects that can affect important aspects of the entire postnatal life, such as the somatic and stature growth and defense against infectious diseases [35]. The gastro-intestinal immune system develops mainly on the basis of the reports that it contracts with the world of bacteria [38] and the development of bacterial flora begins from the moment of birth and continues, especially in humans, with a particular sequence of bacterial strains, that change with different stages of infant nutrition, from breast feeding to weaning [39]. The principle of succession of bacterial micro flora varies in different species of mammals [40]. In the human fetus, it begins with coliform bacteria and enterococci, and it is subsequently followed by bifid bacterium [41]. Some specific nutrients also seem to act as crucial co-factors in the immune response expression [35]. Moreover, the bacterial flora intervenes directly on the digestive function, and for this reason it acts as indirect supplier of nutrients in the gastro-intestinal tract [38]. This, in turn, has an impact on the development of the intestine immune system [37]. This has significant consequences for production of: immunoglobulin A ( $\lg A)$, receptor mfolecules of the major histocompatibility complex (MHC) and intraepithelial lymphocytes [42] (Table 4).

Table 4. Effects of micronutrient intake on the immune response in pregnant women.

\begin{tabular}{ll}
\hline Supplement & Significant effects \\
\hline Multivitamins & $\begin{array}{l}\text { In healthy woman and in elderly they improve } \\
\text { the response to delayed-type hypersensitivity test } \\
\text { (DHT): keep the number of T-helper cells; reduce } \\
\text { morbidity from infectious diseases; increase the } \\
\text { antibody titer in influenza vaccination. }\end{array}$ \\
Vitamin E & $\begin{array}{l}\text { Increase DTH; promotes the proliferation of } \\
\text { immunocytes; improves the antibody titer in } \\
\text { the vaccination against hepatitis B; increases the } \\
\text { production of IL-2; reduces the production of }\end{array}$ \\
& $\begin{array}{l}\text { MPEG2. } \\
\text { Improves the response to the test of delayed-type } \\
\text { Vitamin C }\end{array}$ \\
bypersensitivity (DTH). & $\begin{array}{l}\text { Block the UV-induced immunosuppression in } \\
\text { both young and old patients; improves the } \\
\text { function of NK cells }\end{array}$ \\
\hline
\end{tabular}

DTH: delayed-hypersensitivity skin-test; IL-2: Interleukin-2

\section{Conclusions}

What has been observed clinically in humans, has also been confirmed by experimentation on animals, and this allows us to use this new knowledge to reduce the onset of many diseases. Therefore, it is necessary to understand and know both factors that determine fetal growth and conditions that restrict the provision of maternal-fetal nutrient and oxygen supply to the fetus (Figure 3). So much has been already done, but further studies are needed to understand how the fetus adapts to the limited supply of nutrients from mother, how

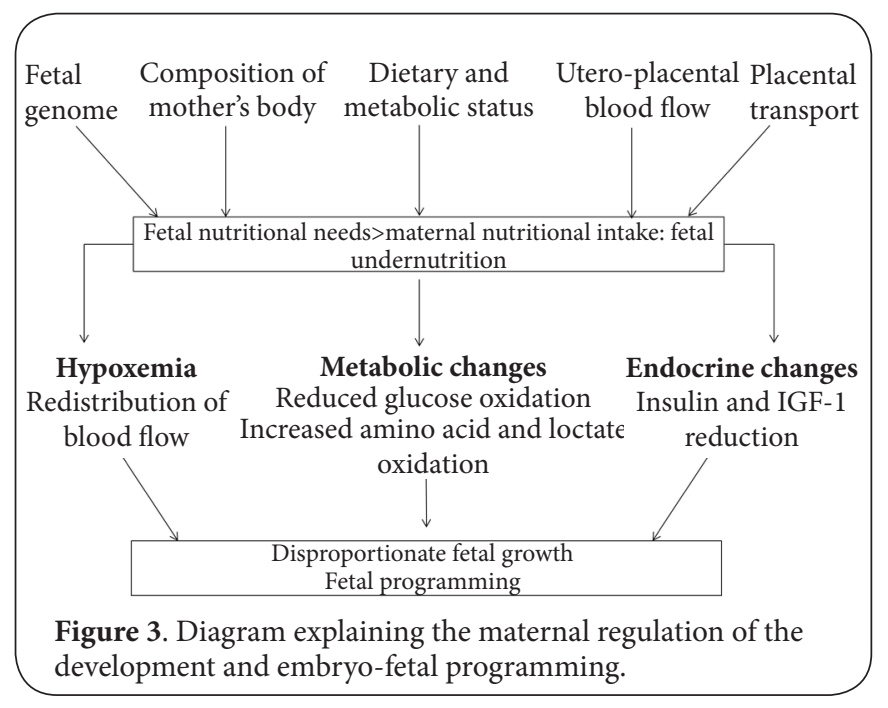

these adaptations influence body structure and physiology, and by which molecular mechanisms, nutrients and hormones can alter the gene expression. We believe that, for the improvement of the pregnancy outcomes, the promotion of healthy growth and development, the reduction of the risk of chronic diseases and the slowing down of the metabolic decline associated with aging, it is necessary to develop dietary strategies to optimize the nutrition not only during the pregnancy, but already at the time in which it is planned, through the intake of adequate micronutrients, of complementary foods and also by the promotion of breast feeding.

\section{List of abbreviations \\ 5-HT: Serotonin \\ cAMP: Cyclic adenosine monophosphate \\ GH: Growth hormone \\ GMP: Guanosine monophosphate \\ IgA: Immunoglobulin A \\ IGFs: Insulin-like growth factors \\ L-Tp: L-tryptophan \\ MHC: Major histocompatibility complex}

\section{Competing interests}

The authors declare that they have no competing interests.

Authors' contributions
\begin{tabular}{|l|c|c|c|c|c|c|}
\hline Authors' contributions & GM & PC & FMT & RP & MAS & RI \\
\hline Research concept and design & $\checkmark$ & $\checkmark$ & -- & -- & $\checkmark$ & $\checkmark$ \\
\hline Collection and/or assembly of data & $\checkmark$ & $\checkmark$ & $\checkmark$ & $\checkmark$ & $\checkmark$ & -- \\
\hline Data analysis and interpretation & $\checkmark$ & $\checkmark$ & $\checkmark$ & $\checkmark$ & $\checkmark$ & -- \\
\hline Writing the article & $\checkmark$ & -- & -- & -- & $\checkmark$ & $\checkmark$ \\
\hline Critical revision of the article & $\checkmark$ & $\checkmark$ & $\checkmark$ & $\checkmark$ & $\checkmark$ & $\checkmark$ \\
\hline Final approval of article & $\checkmark$ & $\checkmark$ & $\checkmark$ & $\checkmark$ & $\checkmark$ & $\checkmark$ \\
\hline Statistical analysis & -- & -- & -- & $\checkmark$ & $\checkmark$ & $\checkmark$ \\
\hline
\end{tabular}




\section{Acknowledgement and funding}

This study was supported by grants provided by FIR 2014-2016, University of Catania, Italy. The authors would like to thank Prof. lain Halliday for commenting and making corrections to the paper.

Publication history

Editor: Lingyan Wang, Oregon Health \& Science University, Portland. Received: 18-Nov-2014 Final Revised: 24-Dec-2014

Accepted: 29-Dec-2014 Published: 03-Jan-2015

\section{References}

1. Minkin MJ. Embryonic development and pregnancy test sensitivity: the importance of earlier pregnancy detection. Womens Health (Lond Engl). 2009; 5:659-67. | Article | PubMed

2. Whyte JJ, Alexenko AP, Davis AM, Ellersieck MR, Fountain ED and Rosenfeld CS. Maternal diet composition alters serum steroid and free fatty acid concentrations and vaginal pH in mice. J Endocrinol. 2007; 192:75-81. | Article | PubMed

3. Siemieniuch MJ, Majewska M, Takahashi M, Sakatani M, Lukasik K, Okuda $\mathrm{K}$ and Skarzynski DJ. Are glucocorticoids auto- and/or paracrine factors in early bovine embryo development and implantation? Reprod Biol. 2010; 10:249-56. | Article | PubMed

4. Williams L, Seki Y, Vuguin PM and Charron MJ. Animal models of in utero exposure to a high fat diet: a review. Biochim Biophys Acta. 2014; 1842:507-19. | Article | PubMed

5. Zerfu TA and Ayele HT. Micronutrients and pregnancy; effect of supplementation on pregnancy and pregnancy outcomes: a systematic review. Nutr J. 2013; 12:20. | Article | PubMed Abstract | PubMed Full $\underline{\text { Text }}$

6. Triunfo $S$ and Lanzone A. Impact of maternal under nutrition on obstetric outcomes. J Endocrinol Invest. 2014. | Article | PubMed

7. Reusens B, Ozanne SE and Remacle C. Fetal determinants of type 2 diabetes. Curr Drug Targets. 2007; 8:935-41. | Article I PubMed

8. Imbesi $R$ and Castrogiovanni P. Embryonic and postnatal development in experimental tryptophan deprived rats. A preliminary study. $J \mathrm{Mol}$ Histol. 2008; 39:487-98. | Article | PubMed

9. Gabory A, Attig L and Junien C. Developmental programming and epigenetics. Am J Clin Nutr. 2011; 94:1943S-1952S. | Article | PubMed

10. Ford SP and Long NM. Evidence for similar changes in offspring phenotype following either maternal undernutrition or overnutrition: potential impact on fetal epigenetic mechanisms. Reprod Fertil Dev. 2011; 24:105-11. | Article | PubMed

11. Simpson JL, Bailey LB, Pietrzik K, Shane B and Holzgreve W. Micronutrients and women of reproductive potential: required dietary intake and consequences of dietary deficiency or excess. Part l--Folate, Vitamin B12, Vitamin B6. J Matern Fetal Neonatal Med. 2010; 23:132343. | Article | PubMed

12. Simpson JL, Bailey LB, Pietrzik K, Shane B and Holzgreve W. Micronutrients and women of reproductive potential: required dietary intake and consequences of dietary deficiency or excess. Part II--vitamin D, vitamin A, iron, zinc, iodine, essential fatty acids. J Matern Fetal Neonatal Med. 2011; 24:1-24. | Article | PubMed

13. Munoz $G$ and Bongiorni-Malave I. Influence of dietary protein restriction on ovulation, fertilization rates and pre-implantation embryonic development in mice. J Exp Zool. 1979; 210:253-7 | PubMed

14. Cisterna B, Flach F, Vecchio L, Barabino SM, Battistelli S, Martin TE, Malatesta $M$ and Biggiogera $M$. Can a genetically-modified organismcontaining diet influence embryo development? A preliminary study on pre-implantation mouse embryos. Eur J Histochem. 2008; 52:263-7. | PubMed

15. Kauffman AS, Bojkowska K and Rissman EF. Critical periods of susceptibility to short-term energy challenge during pregnancy: Impact on fertility and offspring development. Physiol Behav. 2010; 99:100-8. | Article | PubMed Abstract | PubMed Full Text

16. Maki RG. Small is beautiful: insulin-like growth factors and their role in growth, development, and cancer. J Clin Oncol. 2010; 28:4985-95. | Article | PubMed Abstract | PubMed Full Text

17. Kaneda M, Akagi S, Watanabe S and Nagai T. Comparison of DNA methylation levels of repetitive loci during bovine development. $B M C$ Proc. 2011; 5 Suppl 4:S3. | Article | PubMed Abstract | PubMed Full Text

18. Evans AC, Mossa F, Walsh SW, Scheetz D, Jimenez-Krassel F, Ireland $\mathrm{JL}$, Smith GW and Ireland JJ. Effects of maternal environment during gestation on ovarian folliculogenesis and consequences for fertility in bovine offspring. Reprod Domest Anim. 2012; 47 Suppl 4:31-7. | Article I PubMed

19. Palinski W. Effect of maternal cardiovascular conditions and risk factors on offspring cardiovascular disease. Circulation. 2014; 129:2066-77. | Article I PubMed

20. Lewandowski AJ and Leeson P. Preeclampsia, prematurity and cardiovascular health in adult life. Early Hum Dev. 2014. | Article | PubMed

21. Whitaker-Azmitia PM. Serotonin and brain development: role in human developmental diseases. Brain Res Bull. 2001; 56:479-85. | Article | PubMed

22. Whitaker-Azmitia PM. Behavioral and cellular consequences of increasing serotonergic activity during brain development: a role in autism? Int J Dev Neurosci. 2005; 23:75-83. | Article | PubMed

23. Blažević $S$, Dolenec $P$ and Hranilović $D$. Physiological consequences of perinatal treatment of rats with 5-hydroxytryptophan. Periodicum Biologorum. 2011; 113:81-6. | Article

24. Hranilovic D, Blazevic S, Ivica N, Cicin-Sain L and Oreskovic D. The effects of the perinatal treatment with 5-hydroxytryptophan or tranylcypromine on the peripheral and central serotonin homeostasis in adult rats. Neurochem Int. 2011; 59:202-7. I Article | PubMed

25. Musumeci G, Loreto C, Trovato FM, Giunta S, Imbesi R and Castrogiovanni P. Serotonin (5HT) expression in rat pups treated with high-tryptophan diet during fetal and early postnatal development. Acta Histochem. 2014; 116:335-43. | Article | PubMed

26. Castrogiovanni P, Musumeci G, Trovato FM, Avola R, Magro G and Imbesi R. Effects of high-tryptophan diet on pre- and postnatal development in rats: a morphological study. Eur J Nutr. 2014; 53:297-308. | Article | PubMed

27. Musumeci G, Trovato FM, Avola R, Imbesi R and Castrogiovanni P. Serotonin/growth hormone/insulin-like growth factors axis on pre- and post-natal development: a contemporary review. OA Anatomy. 2013; 1:12. | Article

28. Etgen AM. Ovarian steroid and growth factor regulation of female reproductive function involves modification of hypothalamic alpha 1-adrenoceptor signaling. Ann N Y Acad Sci. 2003; 1007:153-61. | Article I PubMed

29. Rhind SM, Rae MT and Brooks AN. Environmental influences on the fetus and neonate--timing, mechanisms of action and effects on subsequent adult function. Domest Anim Endocrinol. 2003; 25:3-11. | Article I PubMed

30. Entringer S and Wadhwa PD. Developmental programming of obesity and metabolic dysfunction: role of prenatal stress and stress biology. Nestle Nutr Inst Workshop Ser. 2013; 74:107-20. | Article | PubMed Abstract I PubMed Full Text

31. Skilton MR, Siitonen N, Wurtz P, Viikari JS, Juonala M, Seppala I, Laitinen T, Lehtimaki T, Taittonen L, Kahonen M, Celermajer DS and Raitakari OT. High birth weight is associated with obesity and increased carotid wall thickness in young adults: the cardiovascular risk in young Finns study Arterioscler Thromb Vasc Biol. 2014; 34:1064-8. | Article | PubMed

32. Gaillard R, Steegers EA, Duijts L, Felix JF, Hofman A, Franco OH and Jaddoe VW. Childhood cardiometabolic outcomes of maternal obesity during pregnancy: the Generation R Study. Hypertension. 2014; 63:68391. | Article | PubMed

33. Mullett MD, Cottrell L, Lilly C, Gadikota K, Dong L, Hobbs G and Neal WA. Association between birth characteristics and coronary disease risk factors among fifth graders. J Pediatr. 2014; 164:78-82. | Article | PubMed 
Musumeci et al. Journal of Histology \& Histopathology 2015,

http://www.hoajonline.com/journals/pdf/2055-091X-2-1.pdf

34. El Hajj N, Schneider E, Lehnen H and Haaf T. Epigenetics and life-long consequences of an adverse nutritional and diabetic intrauterine environment. Reproduction. 2014; 148:R111-R120. I Article I PubMed

35. Palmer AC. Nutritionally mediated programming of the developing immune system. Adv Nutr. 2011; 2:377-95. | Article | PubMed Abstract | PubMed Full Text

36. Fisher RE, Steele $M$ and Karrow NA. Fetal programming of the neuroendocrine-immune system and metabolic disease. J Pregnancy. 2012; 2012:792934. | Article | PubMed Abstract | PubMed Full Text

37. Strzepa $A$ and Szczepanik M. [Influence of natural gut flora on immune response]. Postepy Hig Med Dosw (Online). 2013; 67:908-20. | Article | PubMed

38. MacDonald TT and Pettersson S. Bacterial regulation of intestinal immune responses. Inflamm Bowel Dis. 2000; 6:116-22. | PubMed

39. Madan JC, Farzan SF, Hibberd PL and Karagas MR. Normal neonatal microbiome variation in relation to environmental factors, infection and allergy. Curr Opin Pediatr. 2012; 24:753-9. | Article | PubMed Abstract | PubMed Full Text

40. Abt MC and Pamer EG. Commensal bacteria mediated defenses against pathogens. Curr Opin Immunol. 2014; 29:16-22. | Article | PubMed

41. Mansour NM, Heine $\mathrm{H}$, Abdou SM, Shenana ME, Zakaria MK and ElDiwany A. Isolation of Enterococcus faecium NM113, Enterococcus faecium NM213 and Lactobacillus casei NM512 as novel probiotics with immunomodulatory properties. Microbiol Immunol. 2014; 58:559-69. I Article | PubMed

42. Kelly D and Conway S. Bacterial modulation of mucosal innate immunity. Mol Immunol. 2005; 42:895-901. | Article | PubMed

\section{Citation:}

Musumeci G, Castrogiovanni P, Trovato FM, Parenti R, Szychlinska MA and Imbesi R. Pregnancy, embryo-fetal development and nutrition: physiology around fetal programming. J Histol Histopathol. 2015; 2:1. http://dx.doi.org/10.7243/2055-091X-2-1 